\title{
The Nekai Festival and Traditional Governance in Babungo, North West Cameroon
}

\author{
Godwill Kungso Ndzofoa Eno, PhD $^{1^{*}}$ \\ ${ }^{\mathrm{T}}$ Department of History and Archaeology, the University of Dschang, Cameroon
}

\section{Article History}

Received: 22.02 .2021

Accepted: 06.04.2021

Published: 14.04 .2021

Journal homepage:

https://www.easpublisher.com

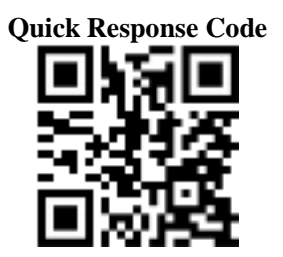

\begin{abstract}
This paper focuses on the Nekai festival as an expression of identity, unity and political stability in Babungo, a Western Grassfields Tikar fondom of Northwest Cameroon. It is a factor of social cohesion, and at the same time a moment to pay homage and allegiance to the leaders and other traditional institutions and power structures that command the traditional governance system of the fondom. The quest for political stability and identity of the traditional "state" through the Nekai festival provides an opportunity to revisit the rich cultural heritage with values of social cohesion deeply rooted in the customs and tradition of the Babungo people. Intense political and religious activities precede the holding of the Nekai festival. It also depicts a special celebration for the achievements of the polity. Interviews were conducted on the field; files were consulted in Buea National Archives while secondary sources were gleaned in libraries. From these sources, investigations reveal that, the Nekai festival is not only an opportunity to celebrate the values of social cohesion, unity, peace and political stability in the fondom, it also allows for an interesting discovery of the polity's dual authority governance system incarnated by two personalities; the Fon with power and authority, and the Bah vested with power and control in the fondom. Although the Nekai festival was meant to valorise the rich customs and identity, it also brought to the fore a conflict of authority at the helm of the traditional "state" governance system. The paper has used an interdisciplinary perspective.
\end{abstract}

Keywords: Babungo, Nekai Festival, Expression of Identity, Political Stability.

Copyright (C) 2021 The Author(s): This is an open-access article distributed under the terms of the Creative Commons Attribution 4.0 International License (CC BY-NC 4.0) which permits unrestricted use, distribution, and reproduction in any medium for non-commercial use provided the original author and source are credited.

\section{INTRODUCTION}

Traditional and cultural festivals are centuries old practices existing within the traditional "states" systems of the polities across the Africa continent. They are mobilising agencies to demonstrate the strength of a people, an expression of identity, unity and political stability. Traditional and cultural festivals are not only a mark of the African continent but also an attachment of African descent. The Brazilian Samba festival is essentially of African extrapolation, demonstrated by the Brazilians of African origin, deported as slaves to the Americas many centuries ago (Ngon Nadine 2019). The steam and strong mobilisation of Brazilians demonstrates the force behind cultural attachments to their traditions of origin which is linked to the African continent. They pay homage to their ancestors through the reproduction of the samba dance. Prominent traditional and cultural festivals in Africa include the Feast of the Yam in the Igbo people, the Ngondo festival of the Sawa, the Ngoen festival of the Bamum, the Lela festival of the Bali-Nyonga and a wide range of others have received wider popular attentions, but leaving out the traditional governance and political dimensions of these festivals. They are reduced to simply cultural events which have gained currency and become part of Africas' cultural heritage.

In the Babungo Fondom, the Nikai is a tool of governance [1] and an important platform within the traditional political system of the polity. Besides the cultural and ritualistic regards to the Nikai festival, this paper is concerned more with the political and governance perspective of the traditional festival with the Nikai of Babungo as the central element of study. The processes, procedures and the crucial role of the power structures and institutions of traditional governance in the Nikai festival assures the independence of the polity as well as the interdependence between the people and the power structures that command the traditional governance system. The people of Babungo governed by their Fon, held tight and preserved their material, social, and spiritual conditions of life through the Nikai festival that guaranteed the political stability and survival of the

\footnotetext{
${ }^{1}$ Traditional governance is a way of ruling a community along lines of models which rely heavily upon traditions, customs, habits and routines in order to regulate human behaviour and to assure stability which permits the group to survive.
} 
political system of the kingdom. In the construction of the Babungo "traditional states", the Nikai festival is the apothéose of a period of intense political and ritual activities carried out by senior traditional state functionaries that incarnate the central axis of traditional governance of the polity. Apart from upholding the rich history of the people, it is an exclusive affaire of the traditional state institutions.

Considering that Nikai is the celeberation of traditional institutions involved in traditional governance, this study is divided in to three parts, the first presents the history of vengo with the origin of Nikai festival in Babungo fondom; the second looks at the political and ritual activities of the traditional institutions; the manifestations of Nekai; then part three discusses the authority conflict in Babungo during the Nekai manifestations.

\section{DISCUSSION}

\section{Part I: An Overview of the Vengo History and the Nekai Festival}

The fondom of Babungo has existed for about 1434 years [2]. Its existence can be compared to that of the Bamun Kingdom. The name Babungo originated from the word Vengo [3] meaning people from the same family. $B a$ means people and vengo means the same family [4] The German explorer, Zintgraff called the place Bamungu [5]. Since then the German and British colonial authorities called it Banbungo, until 1951 when it was written as Babungo [6]. It is a second class fondom according to the 2007 classification of fondoms by the Government of Cameroon [7]. There is a common myth which relates the origin of Babungo people from a waterfall in the area called Forghai which is located east of the present location.

\footnotetext{
${ }^{2}$ J.P. Notué and B. Triaca, Babungo; Treasures of the Sculptor Kings in Cameroon, p, 21.

${ }^{3}$ Ibid, p, 20.

${ }^{4}$ Godwill Kungso Ndzofoa Eno, "Conflict in Traditional Authority System in Babungo, 1900-1990”, Master's Thesis in History, University of Yaounde I, Yaounde, 2013.

${ }^{5}$ Elisabeth M. Chilver, Zintgraff's Exploration in Bamenda, Adamawa and Benue Lands 1881 - 1892, Buea Government Press, 1966, P, 26.

${ }^{6}$ N.A.B, File No $1273 / 1951$, Gazetteer of Place Names on Map of Nigeria; Corrections of Spelling of Place Names in Bamenda Province, 1951, P, 1.

${ }^{7}$ P. N, File No E.31/004/ vol 1, 2007.
}

The present governance institutions that conceived the Nekai festival in Babungo owes its existence to the political inventiveness of the Mange's family. The conception of the "state" structures is linked to the history of origin, migration and settlement which is strongly connected to a myth. Its full development presents the main institutions, incarnated in the Fon and the Bah as leaders, the hierarchical and architectural organisation of the socio-political structures of power. Oral tradition hold that the Babungo people migrated from Ndobo in the Tikar country around the Mbam valley about the twelve century to settle in the present location [8]. The group of migrants was Tiefe Tifuan, considered to be the Fon, Teh Ndiwah, Sorgho, and Nfanyi. There was also a woman, Mange with her three children; Fuanje, Bah and Sainggi (Saingui), who were the architects of state formation of the fondom. In a first stage of their migration, these people occupied a calm and shady area called Forghai, a waterfall. On leaving, the god (Nwi) Forghai gave a black sheep as a guide and instructed them to rest where the sheep stopped to rest and to settle where the sheep died [9].

The point d'appui in the construction of the traditional institutions and the Nekai festival in Babungo began when the group set off on the week-day called Mbaa guided by the sheep. Some distance away from Forghai, Fuanje was tired and decided to settle at a place called Mbenje (meaning incomplete dream, for he did not accomplish the dream of the god to the Promised Land) [10]. After helping Fuanje to settle, the group continued the journey as guided by the sheep. Later, they realised that they had forgotten to bring fire with them, and so sent Sorgho to the god of forghai to ask for fire. The god gave Sorgho fire and a bag containing a thick rope on which human and animal skulls were hung called the Muukwan, which is still the most powerful protection for the fondom [11]. They got to a place called Ngineh where the tired sheep rested. On a day called Mbaa, the sheep died and two days later, it was buried on a week-day called Nkunse. Ngineh became the first settlement of the Babungo people. The first palace was built in this area, with Fuan Sainggi as the first Fon of the fondom. The Bah, eldest son of the Mange, left with his mother and settled in Moukang, a little further from Ngineh. Sorgho, Nswi and Teh Ndiwah remained with the Fon as his retainers

\footnotetext{
${ }^{8}$ Chilver and Kaberry, Traditional Bamenda, p, 21.

${ }^{9}$ This is the myth that constitutes the point d'appui in the creation of the Babungo traditional State.

${ }^{10}$ Kungso, "Conflict in Traditional Authority", ${ }^{11}$ Ibid.
} 
and were made notables in the polity. These people on their hunting experiences in the forest discovered some aborigines.

One of the outstanding political decisions amongst others reached upon arrival and settlement of Vengo was the instauration of the Nekai festival. It was linked to the ritual and political activities of the traditional institutions of governance. The founders of the Babungo polity realised that Nekai was necessary to help the Fon and Bah display real power. The ruling authorities saw that if they governed through institutions that looked like the basis of power, sharing absolute power could be exercised without much opposition. During this period there are intense political and ritual activities across the entire kingdom. Ritual and religious incantations centred on sacred kingship [12] and a cult of dead kings usually to give credibility and importance to the institutions of governance and pay homage to the ancestors prior to the planting season each calendar year. The Nekai festival takes place within last three Nkuunse (between late February and mid-March) and is marked by feasting, contracting of new marriages, renewals of marriage vows, exchange of gifts and family reconciliations. Nkuunse the $8^{\text {th }}$ day of the traditional week, became the traditional day of rest and a feast day still respected in the fondom.

Though the Nekai festival was a moment of reconciliation and peace amongst the citizens of the "traditional State", it was another opportunity in the manifestation of the authority conflict between the Bah [13] and the Fon in Babungo [14]. In a polity with a

\footnotetext{
${ }^{12}$ The "Tikar" chiefdoms have dialectical variations of sacred kingship. To Chilver and Kaberry, the term "Tikar" is a political term implying the legitimacy of sacred kingship.

${ }^{13}$ The $B a h$ is referred to as "Tita $B a h$ ", kingmaker and the Fon's first assistance in Babungo. $\mathrm{He}$ is the executive head of Tifuan. The Bah checked the excesses of the Fon directly and indirectly. Directly, the Bah met the Fon physically to discuss with or gave his opinion over matters in the fondom at any hour of the day to the Fon. Most of their encounters were secret (in the night), without the knowledge of anyone. Indirectly, the Bah used his position within the Tifuan to re-orientate traditional administration, most of the time to the dislike of the Fon.

${ }^{14}$ The creation of a dual authority governance system in Babungo gave birth to a conflict of authority within the traditional governance system in the polity. When the Bah took their mother, Mange with him. The Bah used the presence of their mother to consolidate his power to
}

dual command political system, the traditional festival in Babungo reposed on the interaction between the structures of power represented by the Fon and that of control represented by the Bah (ritual head) in Babungo, who commands the executives of "state constituted authority" (the Tifuan). The Bah and the Fon who rarely discuss and agreed on the agenda and deployments during the festival, the quantity and quality of persons to be initiated in the different chambers and sections of Tifuan. In principle, these two were the essential pillars on which reposed the Nekai festival. Though the Bah and the Fon have vested power and authority, but this does not mean that there are two Fons in Babungo. There is only one Fon and one Bah in Babungo. Each has his place within the traditional political system. By this key consideration, traditional festival and the conflict of authority involved the fon and other aristocrats holding offices which were rooted in the traditional state and other political entities.

\section{Part II: The Political and Ritual Aspects and the Manifestations of Nekai in Babungo}

The fixing a date for commencement of the political and ritual activities leading up to the Nekai festival was agreed by Tifuan in consultations with the Fon and the Bah. Once the period is determined, the local market day, Mfewing, mask agents of Tifuan went round the market announcing to the populace that the Nekai festival will be opened on the first Nkuuse, a resting day, (Sor'ohTifuan). And that the festival will run for three nkuuse, leading up to the planting season. The people as well as senior traditional state functionaries take thier dispositions, each in thier contributions towards the success of the festival. As from this moment, the traditional political machinery is

a strategic position within the authority system of the fondom. He gave proper care and attention that his mother deserved and upon her death told Bah " that when she dies, the Bah should bury her first before informing his brothers Sainggi and Fuanje of her death". The Bah had much favours and divine powers from his mother. In line with the custom and tradition of the Babungo people, the status of a mother is compared to that of God. Thus, for the Bah to have buried the Fon's mother in his compound was a severe blow to the Fon with many implications on him. Firstly, Fuanje, the Fon and the entire community were to pay allegiance to the Bah whenever they came to perform rituals or make sacrifices on their mother's grave, which was obligatory. This again gave the Bah an influential and strategic position within the traditional political system in Babungo. 
gavalnised and are in a state of preparedness to fulfill the mission of the traditional state.

\section{The Political and Ritual Aspects of Nekai Festival}

The institutions of cult shrine that existed in all the traditional political system of the Grassfields to justify the divine authority of the traditional authority and provides an enabling environment for traditional festival. The many rituals and sacrifices performed and in particular those connected with Nekai were done by political institutions and structures within the traditional authority system. These include the structures of Tifuan $\left[{ }^{15}\right]$, the Fon, the Bah and Tita Fuanje. The ritual functions fulfilled by the institutions of cult shrines show the crucial role in the ritual integrations of the traditional governance and political system of the polities of the fondom.

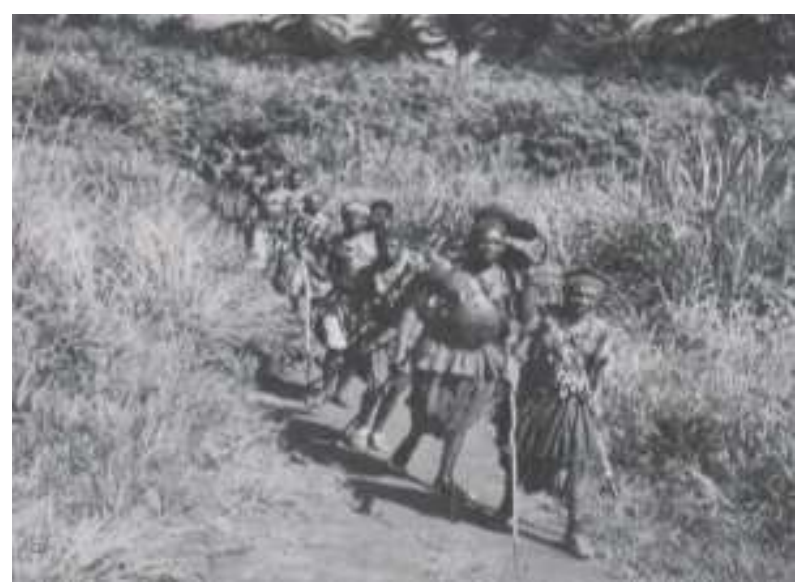

\section{Plate-1: Official body of Tifuan, back from performing sacrifices in prelude to the Nekai Festival}

Source: Godwill Kungso, (2013), p, 85.

This was an official body of Tifuan returning to the Palace after performing sacrifices at the site of the first Babungo palace (Ntoh Ngineh) in 1989.

The Nekai festival opens up with the ritual and religious performances carried out by the traditional institutions and structures most of which are involed in traditional governance. In line with the articles of the « constitutional ordering » related to the festival, agents

\footnotetext{
${ }^{15}$ Tifuan was divided internally into various houses or societies each had its own rights and responsibilities, fetish medicine, masks, costumes and musical instruments, which constitute the juju of the society. The most important structures are the jaw and the nshay. There was also the guu, which had powers to judge witchcraft and other criminal cases.
}

of the constituted authority, Tifuan, performed ritual and religious visits to sites that are home to shrines and Gods of the land. The ritual powers of this body were associated with the fertility of the land and its people, the cult of the royal ancestors and a sacred kingship. The Gods of the land were vital for the promotion of fertility, health, prosperity, peace and justice in the land [16]. Besides, sacrifices were made mainly to ward-off the mystical power with its evil aspect [17].

In Babungo the Mfwei is the institution of the cult shrine. It is a special society that functions outside the palace, but answerable to Tifuan. It is responsible for the peace, protection and cleansing of the kingdom and its members perform their rituals once a year and when there is an abomination in the kingdom [18]. They go out from door to door and from one corner of the kingdom to another performing protection sacrifices [19]. The members of the Mfwei carry special calabashes, gheue mfwei which contains a concoction made from different herbs [20]. These herbs include the Inkegh and the Membua. Besides the Mfwei group is the Vitiitifung another important institution of cult shrine in the Babungo chiefdom. The Tomb priests (vitiitifung) are members of the constituted authority who perform rituals for the preparation of a fruitful New Year. These sacrifices were performed at the sites of Nyui Nka Teng, weei nyei Forghai, Weei nyui Lai and Jo Ngineh [21].

\section{The Fon, the Bah and Tita Fuanje at Ifung Mange and Forghai}

The Fon, the Bah and Fuanje as bearers of political power in Babungo are highly implicated in the ritual stages of the Nekai festival. Ifung Mange [22] and Forghai [23] are the two most important ritual sites that

\footnotetext{
${ }^{16}$ Nkwi, Traditional Government and Social Change, p, 66.

${ }^{17}$ Chilver and Kaberry, Traditional Bamenda, p. 26.

${ }^{18}$ Interview with Ndifuangow Aboubaka, retainer, 69 years, finteng, Babungo, 5th December 2015.

${ }^{19}$ Ibid.

${ }^{20}$ Ibid

${ }^{21}$ Interview with Tita Gounde Mcheal, 71, notable, Finteng, Babungo, 5th December 2015.

${ }^{22}$ Ifung Mange is the hurt covering the grave of the Mother of the Bah, the Fon and Fuanje. The tomb at the palace of the Bah, must be visited by the Fon and the Fuanje, to show respect for thier mother, considered as the mother of the entire kingdom.

${ }^{23}$ Forghai is a waterfall, the place where Mange and her children with those accompanying them during migration, first rested before moving to the present site they now occupy. At Forghai, the gods gave them a
} 
are visited by these trio. In carrying out the rituals at Forghai, the members of their society are naked on approaching the area [24]. Tita Fuanje, putting on the Munkuncho mask opens the activities, under the supervision of Tifuan (the Babungo's version of the regulatory society). Tita Fuanje using a special language announces the arrival of the people to the god. Before reaching the god's dwelling place, a special sound is played using the double gong announcing the arrival of the Tomb priest. This is played at three different points [25]. On each occasion, the leader of the group pleads with the gods to open the way and welcome the people with their gifts. It was believed that if this was not done, the people will not make their way into the cave. At the door steps of the cave, a second plea was made to god to "open the door for the children to bring in their gifts" he then makes way for the group members to go in and perform the rituals.

The ritual is performed with a black cockerel (bi jow), camwood and palm oil. The cock is slaughtered in a special way and thrown in a small pool [26]. There was a special way known only to the tomb priests to find out if the sacrifice was accepted by the gods. It was also at this site that the newly enthroned Fon Ndofoa Zofoa III was presented in 1999 to the god of Forghai with a pure black he-goat [27]. On their way back after performing the rituals, the tomb priests stop at the compound of Tita Fuanje ( being the third personality within the traditional authority system in Babungo after the Fon and the Bah), where they perform other rituals. Sacrifices were offered to Ngesekwa and Fuan Ndo. These same rituals were performed at the sites of all other gods and important sites as a remembrance to the history and identity of the people. It brought about social cohesion and replays the myth that elevates the traditional political system at Babungo. Performing this exercise is an interesting moment in the life of the community which demonstrate unity in the political and governance class of the kingdom. For many years now, getting the Bah and the

black sheep which was thier guide, and instructed that where the sheep died, the migratory famility should bury the sheep and settle there. This people with respect, settled where the sheep died. The significance of Forghai is related to the myth that elevated the leaders of the kingdom.

${ }^{24}$ This sacrifice is being done at night.

${ }^{25}$ Interview with Tita Tifuambalai, 72, notable Babungo's 15 December 2015

${ }^{26}$ Ibid.

260 interview with Tita Sorgho

${ }^{27}$ Ibid
Fon to do this ritual have not possible. The conflict of authority has been raging with on.

Other political activities of the Nekai festival include the graduation of young boys within the rangs of the Tifuan. Their graduation was crowned by the Nekai dance. As for the young boys, it is a great moment of joy especially for those that have gone through the initiation rites. In the chiefdom of Babungo, they are usually given names such as Tumenta, Kometa, Ndula, Ngow, Chinda and Simbo. In the arena you could hear them calling their new names among their peers. These young boys lived in the palace precincts and are taught the custom and tradition of the Babungo people.

\section{The Manifestation of Nikai Festival.}

The Nekai festival takes place in the palace precints or court yard of the Babungo main palace. Early in the morning of the first week day of Nkuuse, the Nekai drum is beaten and the sound is heard in the enitire kingdom. The sound is an indication and a call to everyone that the dancing proper is opened. This period is marked by general euphoria and excitement, for the village has been cleansed and the gods appeased.

\section{Nekai te phor}

The first week of the festival is called Nekai te phor. It is dansed by all the young recruits who just graduated from initation, in the company of other senior men of the community. The dressing code for those dansing this day is leaves worn round the waist and on the head, hence the name Nekai te phor. This is usually not crod pulling given that important personalities in the political and governing class are absent. They are however, sitted in the confines of $\mathrm{Ta}$ fou Tifuan, drinking and perparing the two other series of the festival, namely Meubuh ta nekai and fuan nekai respectively. There is general excitment and euphoria which gathers momentum and could be seen with huge number of people in the market square not far from the palace, scene of action.

Discusions are marked by enthusiasm with plans to participate in the last two sessions of the festival. Most men try to win the hearts of thier women, others try to renew their love relationships of thier ladies and some concluded new marriage deals either getting the women as their first wives or as second or third wives. Its generally a moment of nuptial flights, which accompanies the men in the next two sessions of the festival. For these woment will help prepare thier men as they show case thier talent in the exhibition of the nekai dansing steps. Bates to these women range 
from financial and material wealth to the exhibition of titles and ranks within the traditional political system and governing circles in the kingdom. There are huge exchange of gifts to the families of the newly married girls and display of wealth.

\section{Meubuh ta nekai}

Meubuh ta nekai takes place on the second nkuuse, following the nekai te phor. The mobilisation is impressive and all those that matter in the traditional government bussiness is present. In principle, the Fon, the Bah and Fuanje are all present in this ceremony accompanied by other senior traditional state functionaries. The dancing begins, with the young people animating scene, while waiting for the meubuh ta nekai and the Bah to come on stage. In essence, meubuh ta nekai is the Fon wearing a mask holding two royal spears, enter the dancing areana from the lower part of the palace to meet the others. Simultanously, the Bah carrying the Mba vengo, holding the woughleu, a spear, comes down from Ta fou Tifuan, alongside all the notables particulaly Fuanje, dances slowly till they meet the Fon in mask. They danced to the tune of the drumming music, a few rounds in area then dispersed. The Fon takes the direction of his palace, while the Bah and the nobles return to Ta fou Tifuan.

The implication of this arrangement show the two personalities, the Fon and the Bah as the central axis in a dual command authority system in the polity. The Bah led the dance as Gwejui Ba-Tifuan, founder of the ruling dynasty as well as the laws governing both the people and the political institutions. The Bah commanded respect, prestige and power both in the traditional authority system and from the people. Here the Fon appears as an agent of Tifuan, while visible leadership rest with the Bah. This exihbition demonstrated a duality which reigns at the summit of the traditional political system. For the populace and the senior traditional state functionaries, this deployment recognises and celebrates the leadership role of the Bah who lead the migration of the people from Forghai to the present location. The mba vengo, bag, he carries contain the founding elements and "the constitution", key elements of the customs and tradition of the people. Note should be taken that only the Bah is authorised to carry this bag, but in times of conflict betwen the Bah and the Fon, only Fuanje is allowed to carry it during the Nekai. Though not his role, he substitutes for the $B a h$ as one of the original founders of the kingdom. With the Bah not present during this ceremony, entails disagreement between the two personalities [ 28 ]. Sometimes, Fuanje refuses to play this role, in which case, some other individual within the ranks does it, but usually the said person dies immediately he leaves the ceremonial ground.

\section{Fuan Nekai}

The third and last nkuunse marks the final lap of the Nekai festival. It is named fuan nekai, in view of the fact that the Fon is the centre of attraction during this ceremony. It is a very colourful ceremony heavily attented with invitees streaming in from all over the world. The ceremony makes Babungo a major tourist destination, as there is usually a display of royal traditional artifacts representing symbols of custom and tradition of the polity. During the festival, the Fon and the $B a h$ as well as all other senior traditional state functionaries appeared each dressed in their traditional ceremonial regalia decorated to their rank and social status. The dressing of the Fon and the Bah involved a lavish display of royal treasures and regalia [29]. Special cap woven with black and white threads and decorated with nine turaco red feathers, tingbai and nine porcupine quills, Nsangong were evenly distributed and fitted on the right and left sides of the cap and worn on the fon's head. The Bah was decorated in the same way, but with seven turaco red feathers, tingbai and seven porcupine quills, Nsangong [30]. A necklace made principally of bulges of dark -blue and white beads were thrown around their necks. These ornaments were symbols of nobility, prestige and components of religious powers and authority of the fuan (Fon) and the Bah [31]. The final stages of dressing included the wearing of ivory made bracelets [32] on the right arm and the low over-lapping dress Nkui was worn on the waist line. All the material items described here were symbols of rank and the unchallenged authority of the Fon and the Bah in Babungo. The Nekai festival in Babungo was an event which had great political and symbolic dimension.

\footnotetext{
${ }^{28}$ More on the Fon-Bah conflict constitute the third part of this paper.

${ }^{29}$ Interview with Tita Tifuambalai.

${ }^{30}$ Interview with Tita Ngwitwi.

${ }^{31}$ Ibid.

${ }^{32}$ It must be recalled that such relatively modern articles were first introduced in Babungo following her participation in the extensive trade which was flourishing in the Grassfields region even before the arrival of Europeans. In E.M. Chilver, "Nineteenth Century Trade in Bamenda Grassfields, Southern Cameroons", Afrika and Ubersee, Band XLV14, 1961, PP, 233-258.
} 
The Bah dressed even more gorgeously in cowry decorated traditional attires, carrying the $M b a$ Vengo as Bighai, founder of the ruling dynasty, the "constitutional ordering", that maintains the customs and tradition inforce. He leds the Nekai assisted by Fuanje followed by notables of Moukang [33]. During the ceremony, the Fon display wealth and wishes a better farming season for the kingdom. This is done by the Fon throwing CFA coins and corn seeds to the crowd. Note that this ceremony is the last occasion to the commencement of the planting season. In the deployment of the Nekai festival, the institutions of the Fon and the Bah are being venerated during the ceremonies as described above, clearly stand out as the pivot of traditional governance of the Babungo people. These two power centres with "equal" status play complementary roles for the success of the festival, demonstrates the existence of a duality within the traditional political and governace system of the polity.

\section{Part III: The Nekai Festival and the Manifestation of the Fon-Bah Imbroglio}

For centuries since the existence of the polity, the Nekai festival provided an interesting opportunity for the manifestation of personality cult conflicts within the political and governance class of Babungo. This dualism strongly highlighted by competitive narratives amongst the political and social class constituted the basis of the authority conflict in Babungo. The domineering discussion during the Nekai festivities was centred on the personalities of the Fon and the Bah, who constituted the central axis of traditional governace in Babungo. The Bah who founded the ruling dynasty with the laws governing the people and the institutions, commanded respect, prestige with powers both in the traditional authority and from the people. The customs and tradition of Babungo arrogated much power and authority to the Bah with yet another title Bighai, meaning the root bearer of the kingdom and head of the constituted authority "Tifuan", while the Fon administered the kingdom, as the executive head. But the success of traditional governance and the Nekai festival depended on the interaction between the Fon (power and authority) and the Bah (Power and Control).

With the advent of colonial rule, the German colonial policy of divide and rule accentuated the emergence of the conflict between Fon Sainggi II and Tita Bah in Babungo. Fon Sainggi II was a major collaborator to the German colonial administration in

\footnotetext{
${ }^{33}$ Quarter headed by Chief Bah-Jon Bighai III, present Bah of Babungo.
}

the Ndop area [34]. Seeing the Bah not only as a permanent rival within the traditional political and governance system, Fon Sainggi II saw the Bah as an obstacle to the implementation of his friendship pact [35] with the Germans in the Fondom. Fon Sainggi II saw the German colonial administration as a new-found ally to change the balance of power within the traditional governance system in Babungo to his favour. It was in this context that Fon Sainggi II complained of the lavish display of royal treasures and dominant position of the Bah during the Nekai. In an effort to redress this, an open quarrel ensured.

In 1927, following his accession to the throne, Fon Sake II continued the struggle against the dominant position of the Bah in Babungo. During the installation of Tita Bah, Fon Sake II withheld some important valuable objects which were insignia of power and prestige of the Bah [36]. These included a staff, spear and some beautifully decorated cowry objects such as traditional title pipe, a sword bag, and a metal bangle [ 37 ]. There was also the bangle with a jingle "mbengleuh" the Bah wore on his right arm during the coronation of the Fon. These things were also used by the Bah during the Nekai festival. The Bah requested that these things be refunded, but got no responds. This greatly strained relations between the two.

Kometa Ngehwhy, who was enthroned Bah in 1947, ruled with Fon Sake II, enthroned Fon Zofoa II and the present Fon Ndofoa Zofoa III, and passed away in 2001, attended just two sessions of the Nekai. Before his death he protested for the return of his properties, which was never returned to him. His successor, Chief Bajon-Bihai III, since his assertion to the throne in 2001, has never featured in any of the Nekai festival. His non-participation in the Nikai festival is not only because he is based in the United States of America, but as a result of the authority feud at the helm of the polity.

\footnotetext{
${ }^{34}$ N.P.Nkwi, The German Presence in the Western Grassfields 1891-1913; A German Colonial Account, p, 41.

${ }^{35}$ When Zintgraff visited Babungo in 1889, a friendship pact was reached between Fon Sainggi II and Zintgraff through gifts and servants. This pact consisted of the supply of labour for their plantations and road construction, pay tributes, porters and especially to remain an ally to the German colonial authorities in the area. In return, the Germans were to help subdue all rebellious subjects to the Fon in Babungo.

${ }^{36}$ Interview with Tita Ntuchu.

${ }^{37}$ Ibid.
} 
The toxic approach in the management of the Fon-Bah authority crises in Babungo, both by the Babungo people, the colonial and post-colonial administrative authorities; have not been able to salvage the political stability and unity of the Fondom through the Nekai festival. The Nekai festival that mobilised the entire community from home and abroad over centuries has been hardest hit by the political crisis at the helm of the "traditional state". Increasingly, the huge publicity given to the political crises within the fondom saw the participation of many senior traditional "state" functionaries and the ordinary youths declined considerably. Even the political and ritual perspective of the festival became symbolic.

\section{CONCLUSION}

Basing on the discussion in this paper, the study reveal that, the Nekai festival is not only an opportunity to celebrate the values of social cohesion, unity, peace and political stability in the fondom, it also allows for an interesting discovery of the polity's dual authority governance system incarnated by two personalities; the Fon with power and authority, and the Bah vested with power and control in the fondom. Although the Nekai festival was meant to valorise the rich customs, tradition and identity of the Vengo people also known as Babungo people. In the life of every community, any event organised does not only celebrate the purpose for which it was intended. The political under tone of the Nekai festival shows it urgly head, though the conflict is known only to the actors concerned and othe keen observers.

\section{REFERENCES}

\section{Interviews}

1. Ndifuangow Aboubaka, retainer, 69 years, finteng, Babungo, 5th December 2015.

2. Tita Gounde Mcheal, 71, notable, Finteng, Babungo, 5th December 2015

3. Tita Tifuambalai, 72, notable Babungo's 15 December 2015
4. Tita Tisah, 80 years, notable and retainer during the reign of Fon Sake, Babungo, 1997.

5. Tita Ntuchu, 90 years, notable and retired civil administrator, Bamenda, 2001.

\section{Archival Documentation}

1. N.A.B, File $N^{0} 1273 / 1951$, (1951), Gazetteer of Place Names on Map of Nigeria; Corrections of Spelling of Place Names in Bamenda Province, P, 1.

2. R.A.B, File no B3128, (25 ${ }^{\text {th }}$ July 1970$)$, Letter addressed to the District Officer, Ndop Subdivision by Fon Zofoa II.

3. P. N, File No E.31/004/ vol 1, (2007).

\section{Secondary Sources}

1. Chilver, E. M. (1966). Zintgraff's Exploration in Bamenda, Adamawa and Benue Lands 1881 1892, Buea Government Press, 26.

2. Chilver, E.M., \& Kaberry, P.M. (1967). Traditional Bamenda: The Pre-colonial History and Ethnography of the Bamenda Grassfields, Buea, Ministry of Primary Education and Social Welfare and West Cameroon Antiquities Commission, p, 1.

3. Godwill, K. N. E. (2013). "Conflict in Traditional Authority System in Babungo, 1900-1990", Master's Thesis in History, University of Yaounde I, Yaounde, 66-89. (UMI N ${ }^{\circ}$ 02H271)

4. Nkwi, P.N. (1976). Traditional Government and Social Change, University Press Fribourg,

5. Switzerland, 78-98.

6. Chilver, E. M. (1961). "Nineteenth Century Trade in Bamenda Grassfields, Southern Cameroons", Afrika and Ubersee, Band XLV14, 233-258.

7. Nkwi, P.N. (1989). The German Presence in the Western Grassfield 1891-1913, A German Colonial Account, Leiden, African Study Centre, 41.

8. Nkwi P.N., \& Warnier, J.P, (1982). Elements for History of the Western Grassfield, Yaoundé, 56-74.

9. Notué, J.P., \& Triaca B. (2006). Babungo; Treasures of the Sculptor Kings in Cameroon, 5continents Editions, Milan, Italy, 45-57.

Cite This Article: Godwill Kungso Ndzofoa Eno (2021). The Nekai Festival and Traditional Governance in Babungo, North West Cameroon. EAS J Humanit Cult Stud, 3(2), 103-110. 